(C) Тончева К.Д., Король Д.М., Тончев М.Д., Козак Р.В., Запорожченко І.В.

УДК 616.742.6/7-007-06:616.831-005.1:616-07

DOI https://doi.org/10.31718/mep.2020.24.1-2.10

\title{
ДІАГНОСТИКА ПОРУШЕНЬ РОБОТИ ЖУВАЛЬНИХ М'ЯЗІВ ТА КОЛОВОГО М'ЯЗА РОТА У ПАЦІЄНТІВ З ІНСУЛЬТОМ (КЛІНІЧНИЙ ВИПАДОК)
}

\author{
Тончева К.Д ${ }^{1}$, Король Д.М ${ }^{1}$, Тончев М.Д ${ }^{2}$, Козак P.В., ${ }^{1}$ Запорожченко І.В. ${ }^{1}$ \\ ${ }^{1}$ Українська медична стоматологічна академія, м. Полтава \\ ${ }^{2}$ Комунальне підприємство «Полтавська обласна клінічна лікарня ім. М.В. Скліфосовського», м. Полтава
}

у даній статті автори звертають увагу на необхідність відновлення жувальної функції у пацієнтів з такою общесоматической патологією як інсульт для повноцінної реабілітації. Метою даного дослідження була діагностика порушень роботи жувальної і мімічної мускулатури у пацієнтів з ускладненим перебігом гострого порушення мозкового кровообігу по гемітіпу для подальшої розробки та проведення відповідного комплексного лікування. Автори на прикладі трьох пацієнтів з різним розташуванням вогнища патології вибрали метод функціональної ЕМГ як один 3 найбільш інформативних, оскільки він застосовується з метою визначення фаз м'язової активності циклу руху, дослідження амплітуди і тривалості дії, а також дає можливість для пацієнта отримати зворотній зв'язок про правильність реалізації стереотипу руху. Інформація, отримана при проведенні ЕМГ дозволяє зробити вибір правильної реабілітаційної стратегії. Дані електроміографічних досліджень біоелектричної активності м'язів пацієнтів з геміпарезом/геміплегією внаслідок гострого порушення мозкового кровообігу $\epsilon$ інформативними і відображають зміну рухової функції жувальних і мімічних м'язів даної категорії хворих. Дана робота показала, що в залежності від локалізації ураження головного мозку має місце гіпертонус при ураженні центральних частин і гіпотонус при ураженні периферичних частин мезга, що в свою чергу вимагає різної тактики в реабілітаційному процесі пацієнтів перенесли інсульт.

Ключові слова: електроміографрія, інсульт, жувальні м'язи, коловий м'яз рота, геміпарез, геміплегія.

In this article, the authors draw attention to the need to restore masticatory function in patients with such a somatic pathology as stroke for full rehabilitation. The purpose of this study was to diagnose malfunctioning of the masticatory and facial muscles in patients with a complicated course of acute cerebrovascular accident by hemitype for the further development and implementation of appropriate comprehensive treatment. On the example of three patients with a different location of the pathology location, the authors chose the functional EMG method as one of the most informative, as it is used to determine the phases of the muscle activity of the movement cycle, to study the amplitude and duration of action, and also provides an opportunity for the patient to receive feedback on the correct implementation stereotype of movement. The information obtained during the EMG allows you to choose the right rehabilitation strategy. The data of electromyographic studies of the bioelectric activity of the muscles of patients with hemiparesis / hemiplegia due to acute cerebrovascular accident are informative and reflect a change in the motor function of the masticatory and facial muscles of this category of patients. This work showed that, depending on the location of the brain lesion, there is hypertonicity in lesions of the central parts and hypotonicity in lesions of the peripheral parts of the brain, which in turn requires different tactics in the rehabilitation process of stroke patients.

Key words: electromyography, stroke, chewing muscles, circular muscles of the mouth, hemiparesis, hemiplegia.

\section{Вступ}

Однією зі складових реабілітації пацієнтів з ускладненим перебігом гострого порушення мозкового кровообігу $€$ відновлення акту жування, ковтання та утримання їжі в ротовій порожнині, адже наслідками даної патології $є$ порушення координованої дії нервово-м'язевого апарату зубо-щелепної ділянки. Відновлення порушених рухових функцій, що виникли внаслідок інсульту, є однією з найважливіших задач сучасної медицини $[1,3,8]$.

Рухові порушення розвиваються у $80-85 \%$ пацієнтів у гострому періоді та у $60 \%$ з них спостерігаються залишкові явища різного ступеня вираженості через 6 міс після інсульту $[10,11]$. У даної категорії пацієнтів відмічається не тільки зниження сили м'язів, а й порушується довільна діяльність в результаті ураження частин мозку, що відповідають за моторику [1]. Відмі- чається розлад координації м'язів та порушення регуляції рухів, що проявляється неузгоденістю між собою в належному тимчасовому та/або силовому відношенні та невідповідністю моторної команди м'язам і рухом, який виникає внаслідок неї $[3,4]$.

За даними літератури близько $30 \%$ пацієнтів, що страждають на інсульт, складають категорію працездатного населення. Порушення злагодженої роботи нервово-м'язевого апарату щелепно-лицевої ділянки обмежує активність у повсякденному житті $[2,6]$, знижуючи якість життя і впливаючи на психологічний і емоційний стан пацієнта $[7,12]$.

Метою дослідження є діагностика порушень роботи жувальної та мімічної мускулатури у пацієнтів 3 ускладненим перебігом гострого порушення мозкового кровообігу по гемітипу для подальшої розробки та проведення відповідного комплексного лікування.

\footnotetext{
* Цитування при атестації кадрів: Тончева К.Д., Король Д.М., Тончев М.Д., Козак Р.В., Запорожченко І.В. Діагностика порушень роботи жувальних м'язів та колового м'яза рота у пацієнтів з інсультом (клінічний випадок) // Проблеми екології і медицини. - 2020. - T. 24, № 1-2. - С. 44-48.
} 


\section{Матеріали та методи дослідження}

Оцінка ефективності реабілітації ґрунтується на аналізі рухових і функціональних можливостей пацієнта за допомогою клінічних шкал, інструментальних методів, методів просторового аналізу рухів [9].

Метод функціональної електроміографії (ЕМГ) дозволяє отримувати інформацію про якість іннервації м'язів, оцінити їх функціональний стан при виконанні фрізіологічної дії та у випадку виникнення патологічних змін, вивчити координацію рухів, сприяти функціональній перебудові ушкоджених м'язів і контролювати їх втомлюваність, а також виробити руховий досвід при русі губ та нижньої щелепи [5].

Метод функціональної ЕМГ як один з найбільш інформативних, застосовується з метою визначення фаз м'язової активності циклу руху, дослідження амплітуди і тривалості дії, а також дає можливість для пацієнта отримати зворотній зв'язок про правильність реалізації стереотипу руху [4]. Інфрормація, отримана під час проведення ЕМГ дозволяє зробити вибір правильної реабілітаційної стратегії. Дослідження проводилося на двоканальному нейрофрізіологічному комп'ютерному комплексі «Нейро-МВП-Микро» (Санкт-Петербург).

Дослідження виконано відповідно до етичних принципів Гельсінської декларації. Було обстежено 3 особи з геміпарезом/геміплегією, що виник внаслідок гострого порушення мозкового кровообігу (2 чоловіка та 1 жінка), середній вік яких становив 65,3роки. При цьому проводилася стимуляційна електроміограсрія, при якій реєструється електрична відповідь м'яза на стимуляцію інервуючого нерва.

Вказаний варіант ЕМГ традиційно використовують у нейростоматології та хірургічній стоматології при пошкодженні лицьового нерва для визначення його провідності та швидкості, розповсюдження по нерву, для визначення ступеня парезу мімічної мускулатури.
Враховуючи основну патологію хворих, дослідження проводилося у стані фізіологічного спокою. Після знежирення шкіри накладали електроди на коловий м'яз рота, переднє черевце двочеревцевого м'яза, власне жувальний м'яз та підборідний, спочатку на здоровій стороні, а потім на ураженій; заземлення на передпліччі.

Основними параметрами при аналізі ЕМГ були: амплітуда, тривалість та тимчасовий перебіг біоелектричної активності, та найважливіше - співвідношення активності симетричних м'язів правої та лівої сторін. Також важливим кількісним параметром ЕМГ є загальна величина електричної активності м'яза та частота проходження коливань. В нормі частота коливань при інтенсивних скороченнях велика, близько 100 кол/с і майже не пов'язана з силою скорочення м'яза, ЕМГ виглядає «насиченою». При наявності порушень фрункцій нервово-м'язового апарату, при слабких скороченнях м'яза ЕМГ може виглядати «ненасиченою», в ній розрізняють окремі коливання. Середньостатистичний показник амплітуди (мВ), згідно даних літератури, прийнятий за 2,0 мВ. Час стимуляції 0,2мс. [1]

\section{Результати та їх обговорення}

Клінічний випадок №1. Пацієнт Н., 62 роки, ранній відновний період, геміпарез внаслідок аневризми передньої нижньої мозочкової артерії з проривом у шлуночкову систему. Проведено ЕМГ musculus Digastricus, musculus Masseter, musculus Orbicularis oris 3 правої та лівої сторін. Результати обстеження показали наявну асиметрію роботи жувальних м'язів та колового м'яза рота правої та лівої сторін. Проаналізувавши дані ЕМГ у даного пацієнта отримали відповідні результати, які наведені в табл.1. Переднє черевце двочеревцевого м'яза правої та лівої сторони відрізняються як амплітудою так і довжиною імпульсу, а це свідчить про наявний дисбаланс у роботі м'язів та може свідчити про утруднене ковтання (рис 1).

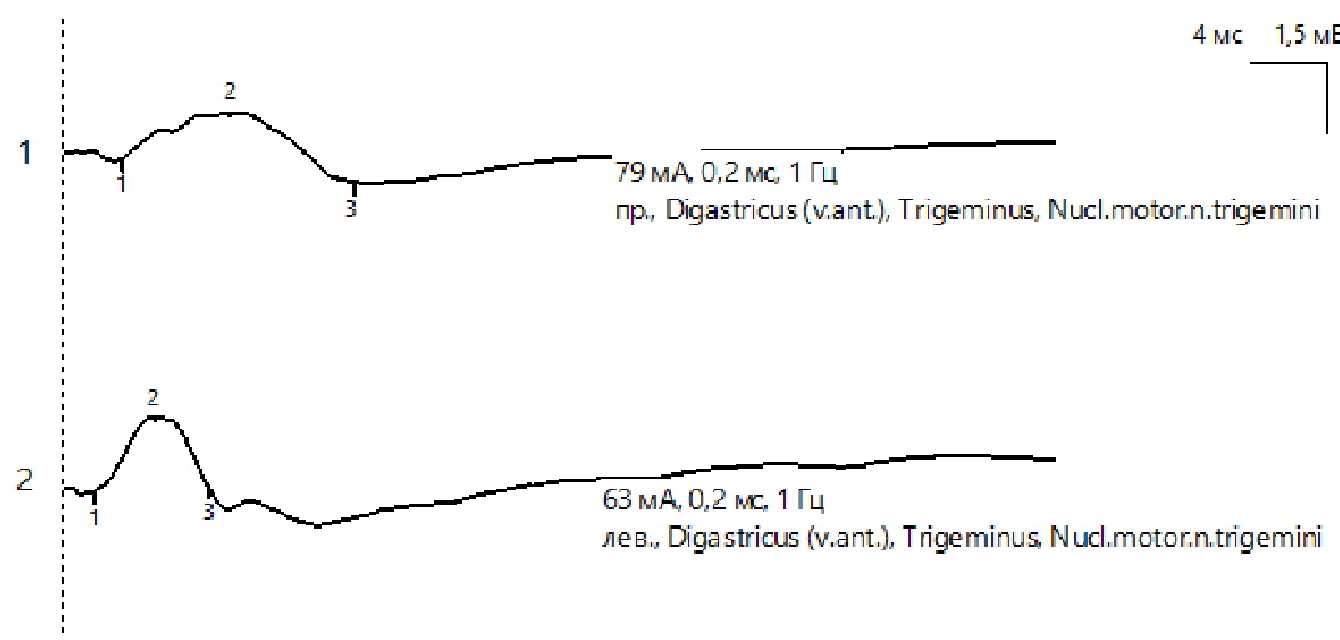

Puc. 1. ЕМГ musculus Digastricus пацієнта з ...ееміпарезом

Що стосується власне жувального м'яза, то спостерігаються незначні відмінності один від одного, але це впливає на якість пережовування їжі. Тонус колового м'яза рота з обох сторін знижений у порівнянні із середньостатистичною нормою (2мB): з правої сторони на $61,3 \%, 3$ лівої - на $73,4 \%$, що в свою чергу ускладнює прийом їжі. Також необхідно звернути увагу, що у пацієнтів з інсультом не завжди з першої спроби можна виміряти біоелектричні імпульси м'язів, на відміну від здорових людей у загальносоматичному плані. 
ToM 24, N 1-2 2020 p.

Таблиця 1

Основні параметри ЕМГ пацієнта Н. з геміпарезом внаслідок аневризми передньої нижньої мозочкової артерії з проривом у шлуночкову систему

\begin{tabular}{|c|c|c|c|c|c|c|c|}
\hline Проба & $\begin{array}{c}\text { Точка } \\
\text { стимуляції }\end{array}$ & $\begin{array}{l}\text { Лат., } \\
\text { мс }\end{array}$ & $\begin{array}{c}\text { Ампл., } \\
\text { мВ }\end{array}$ & $\begin{array}{c}\text { Довж., } \\
\text { мс }\end{array}$ & $\begin{array}{l}\text { Площ., } \\
\text { мВ×мс }\end{array}$ & $\begin{array}{c}\text { Стим., } \\
\text { мА }\end{array}$ & $\begin{array}{c}\text { Стим., } \\
\text { мс }\end{array}$ \\
\hline \multicolumn{8}{|c|}{ пр., Digastricus (v.ant.), Trigeminus, Nucl.motor.n.trigemini } \\
\hline 2 & & 3,0 & 1,0 & 11,6 & 6,7 & 79 & 0,2 \\
\hline \multicolumn{8}{|c|}{ лів., Digastricus (v.ant.), Trigeminus, Nucl.motor.n.trigemini } \\
\hline 2 & & 1,6 & 1,6 & 5,69 & 5,3 & 63 & 0,2 \\
\hline \multicolumn{8}{|c|}{ пр., m. Masseter } \\
\hline 3 & & 2,8 & 1,7 & 9,32 & 10,0 & 88 & 0,2 \\
\hline \multicolumn{8}{|c|}{ лів., m. Masseter } \\
\hline 4 & & 2,6 & 2,6 & 8,78 & 11,7 & 90 & 0,2 \\
\hline \multicolumn{8}{|c|}{ пр., Orbicularis oris, Facialis, Nucl.n.facialis } \\
\hline 1 & & 4,6 & 0,8 & 4,02 & 1,7 & 73 & 0,2 \\
\hline \multicolumn{8}{|c|}{ лів., Orbicularis oris, Facialis, Nucl.n.facialis } \\
\hline 1 & & 4,3 & 0,5 & 4,02 & 1,5 & 65 & 0,2 \\
\hline
\end{tabular}

Клінічний випадок №2. Пацієнтка І., 56 років, інсульт ускладнений геміпарезом, ранній відновний період внаслідок внутрішньо-мозкового паренхіматозного крововиливу правої гемісфери з проривом у шлуночкову систему.

Tаблиця 2
Основні параметри ЕМГ пацієнки І. з геміпарезом внаслідок внутрішньо-мозкового паренхіматозного крововиливу
правої гемісфьери з проривом у шлуночкову систему Orbicularis oris та musculus Mentalis, правої та лівої сторін, результати представлені в табл. 2.

\begin{tabular}{|c|c|c|c|c|c|c|c|}
\hline Проба & $\begin{array}{c}\text { Точка } \\
\text { стимуляції }\end{array}$ & $\begin{array}{l}\text { Лат., } \\
\text { мс }\end{array}$ & $\begin{array}{c}\text { Ампл., } \\
\text { мВ }\end{array}$ & $\begin{array}{l}\text { Довж., } \\
\text { мс }\end{array}$ & $\begin{array}{l}\text { Площ., } \\
\text { мВ×мс }\end{array}$ & $\begin{array}{c}\text { Стим., } \\
\text { мА }\end{array}$ & $\begin{array}{c}\text { Стим., } \\
\text { мс }\end{array}$ \\
\hline \multicolumn{8}{|c|}{ пр., Mentalis, Facialis, Nucl.n.facialis } \\
\hline 1 & & 3,3 & 2,0 & 7,96 & 10,0 & 37 & 0,2 \\
\hline \multicolumn{8}{|c|}{ лів., Mentalis, Facialis, Nucl.n.facialis } \\
\hline 2 & & 3,4 & 3,3 & 7,67 & 12,1 & 53 & 0,2 \\
\hline \multicolumn{8}{|c|}{ пр., m. Masseter } \\
\hline 4 & & 2,3 & 1,7 & 9,95 & 10,7 & 59 & 0,2 \\
\hline \multicolumn{8}{|c|}{ лів., m. Masseter } \\
\hline 5 & & 2,3 & 2,3 & 8,75 & 8,0 & 51 & 0,2 \\
\hline \multicolumn{8}{|c|}{ пр., Orbicularis oris, Facialis, Nucl.n.facialis } \\
\hline 3 & & 2,0 & 0,7 & 8,33 & 2,7 & 54 & 0,2 \\
\hline \multicolumn{8}{|c|}{ лів., Orbicularis oris, Facialis, Nucl.n.facialis } \\
\hline 3 & & 2,7 & 3,9 & 5,36 & 11,9 & 45 & 0,2 \\
\hline
\end{tabular}

За даними ЕМГ у даної пацієнтки спостерігалося підвищений тонус musculus Orbicularis oris зліва на $96 \%$, та знижений з правої сторони на $66 \%$, врахову-

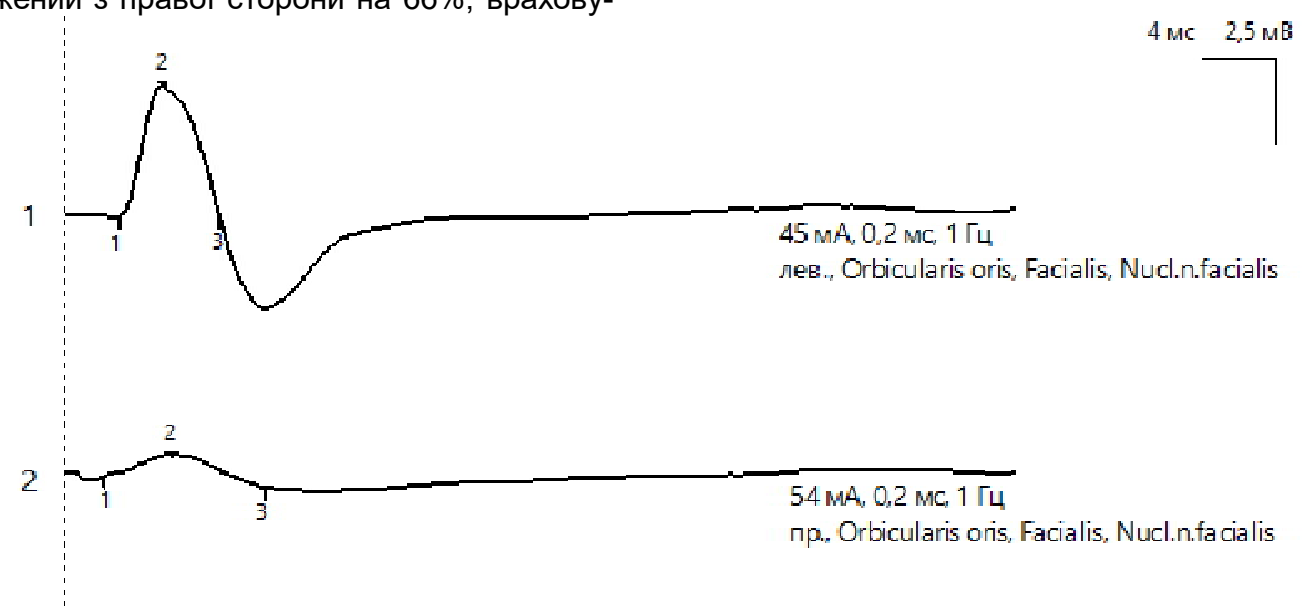

Puc. 2. ЕМГ musculus Orbicularis oris пацієнтки з правостороннім геміпарезом.

Tонус musculus Mentalis зліва збільшений на $67 \%$, в той час як правий - відповідає нормі. Тонус власне жувальних м'язів справа і зліва незначно відрізняються від норми, але значно відрізняються криві ЕМГ ючи, що сила стимуляції та довжина імпульсу більші у порівнянні з лівою стороною (рис. 2).

(рис. 3,4), що свідчить про дисгармонію у роботі нервово-м'язевого апарату щелепно-лицевої ділянки пацієнтки, що в свою чергу утруднює прийом та пережовування їжі. 


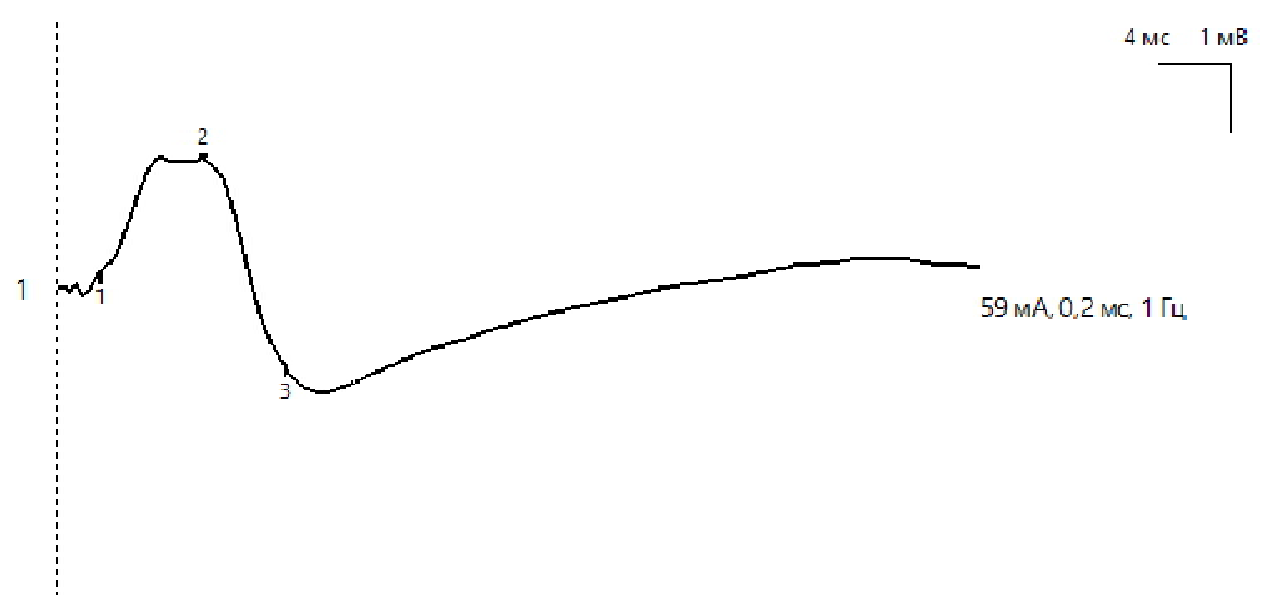

Puc. 3. ЕМГ musculus Masseter dextra пацієнтки з правостороннім геміпарезом.

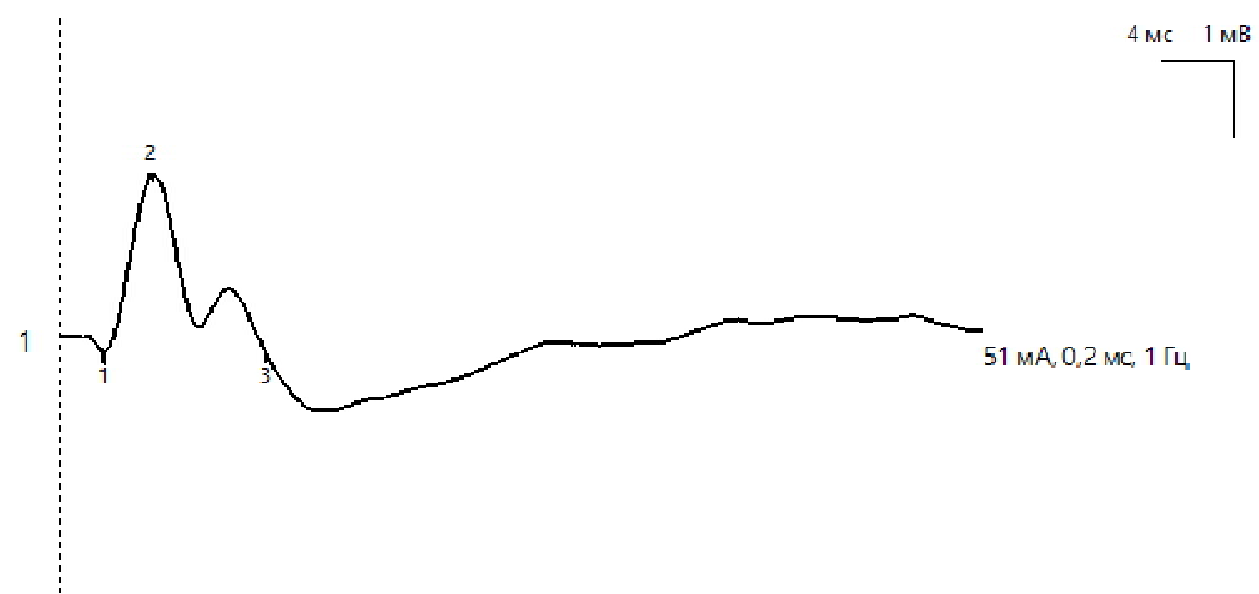

Puc. 4. ЕМГ musculus Masseter sinistra пацієнтки з правостороннім геміпарезом.

Клінічний випадок №3. Пацієнт Р., 78 років, з лівосторонньою геміплегією центрального ґенезу внаслідок артеріовенозної мальформації скронево-тім'янопотиличної ділянки справа з паренхіматозним кровови-

ливом. Проведено ЕМГ musculus Digastricus, musculus Masseter, musculus Orbicularis oris та musculus Mentalis, 3 правої та лівої сторін. За результатами обстеження отримали відповідні дані, які наведені в табл.3.

Таблиця 3

Основні параметри ЕМГ пацієнта Р. з лівосторонньою геміплегією центрального ґенезу внаслідок артеріовенозної мальформації скронево-тім'яно-потиличної ділянки справа з паренхіматозним крововиливом

\begin{tabular}{|c|c|c|c|c|c|c|c|}
\hline Проба & $\begin{array}{c}\text { Точка } \\
\text { стимуляції }\end{array}$ & $\begin{array}{c}\text { Лат., } \\
\text { мс }\end{array}$ & $\begin{array}{c}\text { Ампл., } \\
\text { мВ }\end{array}$ & $\begin{array}{c}\text { Довж., } \\
\text { мс }\end{array}$ & $\begin{array}{l}\text { Площ., } \\
\text { мВ×мС }\end{array}$ & $\begin{array}{c}\text { Стим., } \\
\text { мА }\end{array}$ & $\begin{array}{c}\text { Стим., } \\
\text { мс }\end{array}$ \\
\hline \multicolumn{8}{|c|}{ пр., Digastricus (v.ant.), Trigeminus, Nucl.motor.n.trigemini } \\
\hline 4 & & 2,6 & 3,4 & 8,71 & 9,9 & 32 & 0,2 \\
\hline \multicolumn{8}{|c|}{ лів., Digastricus (v.ant.), Trigeminus, Nucl.motor.n.trigemini } \\
\hline 4 & & 2,6 & 4,0 & 6,07 & 11,6 & 32 & 0,2 \\
\hline \multicolumn{8}{|c|}{ пр., m. Masseter } \\
\hline 5 & & 2,4 & 3,5 & 6,84 & 12,0 & 41 & 0,2 \\
\hline \multicolumn{8}{|c|}{ лів., m. Masseter } \\
\hline 6 & & 2,2 & 4,8 & 7,16 & 18,7 & 45 & 0,2 \\
\hline \multicolumn{8}{|c|}{ пр., Orbicularis oris, Facialis, Nucl.n.facialis } \\
\hline 3 & & 4,2 & 3,4 & 6,13 & 11,0 & 45 & 0,2 \\
\hline \multicolumn{8}{|c|}{ лів., Orbicularis oris, Facialis, Nucl.n.facialis } \\
\hline 3 & & 3,8 & 2,6 & 5,92 & 9,1 & 47 & 0,2 \\
\hline \multicolumn{8}{|c|}{ пр., Mentalis, Facialis, Nucl.n.facialis } \\
\hline 1 & & 3,0 & 4,5 & 6,28 & 15,0 & 48 & 0,2 \\
\hline \multicolumn{8}{|c|}{ лів., Mentalis, Facialis, Nucl.n.facialis } \\
\hline 2 & & 3,3 & 1,1 & 5,0 & 2,4 & 47 & 0,2 \\
\hline
\end{tabular}

У даного пацієнта ми спостерігали незначні відмінності у показниках ЕМГ двочеревцевого м'яза. При вивченні власне жувального м'яза відзначалась необхідність більшої стимуляції лівого м'яза для отриман- ня імпульсу. Параметри амплітуди колового м'яза рота збільшені від середньостатистичної норми з правої сторони на $68,2 \%$, з лівої - на $30 \%$, що свідчить про постійний тонус. Амплітуда musculus Mentalis справа 
ToM 24, N 1-2 2020 p.

збільшена на $123 \%$, в той час як зліва незначно знижена від норми, що свідчить про дискоординацію у роботі даних м'язів.

\section{Висновок}

Дані електроміографічних досліджень біоелектричної активності м'язів пацієнтів 3 геміпарезом/геміплегією внаслідок гострого порушення мозкового кровообігу $€$ інформативними і відображають зміну рухової фрункції жувальних та мімічного м'язів даної категорії хворих.

Електроміографія показала, що в залежності від локалізації ураження головного мозку має місце гіпертонус при ураженні центральних частин та гіпотонус при ураженні перифреричних частин мозку.

Проаналізувавши наведені клінічні випадки, необхідність подальшого детального вивчення нервовом'язевого апарату щелепно-лицевої ділянки у пацієнтів з інсультом для узагальнення даних, подальше удосконалення проведення методики для вибору методики лікування та оцінки та динамічного спостереження реабілітаційних заходів $є$ вкрай актуальною та розширяє перспективи ефективної реабілітації стоматологічних пацієнтів з вторинною частковою адентією та супутньою патологією неврологічного характеру .

\section{Література}

1. Белова А.Н. Реабилитационное обследование больных с нарушением двигательных функций. Руководство по реабилитации больных с двигательными нарушениями. М.: АОЗТ «Антидор»; 1988.

2. Міщенко Т.С. Епідеміологія неврологічних захворювань в Україні. Нейро News. 2008;№3:76-77. https://doi.org/10.17116/jnevro201711712294-101
3. Николаев С. Г., Электромиография: клинический практикум. Иваново; 2013. 264 с.

4. Скворцов Д.В., Кауркин С.Н., Иванова Г.Е., Лобов А.Н., Журавлева А.Н. Динамика функции мышц плечевого пояса у больных с гемипарезом в остром периоде каротидного инсульта. Журнал неврологии и психиатрии. 2017;12(2):94-100.

5. Смаглюк Л.В., Ляховська А.В. Електроміографрія жувальних м'язів як метод об'єктивізації результатів лікування пацієнтів із дисфункцією скронево-нижньошелепного суглоба. Світ ортодонтії, 2016;1:10-16.

6. Тончева К. Д., Король Д.М., Тончев М.Д. Перспективи використання біологічного зворотного зв'язку в щелепно-лицьовій ділянці в процесі реабілітації хворих 3 ускладненим перебігом гострого порушення мозкового кровообігу. Ендоваскулярна нейрорентгенохірургія. 2018;T. 25 (3):76-81.

7. Dipietro L, Ferraro M, Palazzolo JJ, Krebs HI, Volpe BT, Hogan N. Customized interactive robotic treatment for stroke: EMG-triggered therapy. IEEE Trans Neural Syst Rehabil Eng. 2005;13(3):325-334.

8. Garrison S, Rolak L. Rehabilitation of the stroke patient. In: Rehabilitation medicine; principles and practice. Ed. by J. De Lisa. Philadelphia: Lippincott Company; 1993.

9. Hingtgen B. An upper extremity kinematic model for evaluation of hemiparetic stroke. $J$ Biomech. 2006;39(4):681-688.

10. Morris JH, van Wijck F, Joice S, Donaghy M. Predicting health related quality of life 6 months after stroke: the role of anxiety and upper limb dysfunction. Disability and Rehabilitation. 2013;35(4):291-299.

11. Veerbeek JM, Kwakkel G, van Wegen EE, Ket JC, Heymans MW. Early prediction of outcome of activities of daily living after stroke: a systematic review. Stroke. 2011;42:1482-1488.

12. Yancosek KE, Howell D. A narrative review of dexterity assessments. J Hand Ther. 2009; 22:258-269.

Матеріал надійшов до редакції 05.02.2020. 